Historic, Archive Document

Do not assume content reflects current scientific knowledge, policies, or practices. 

62,34
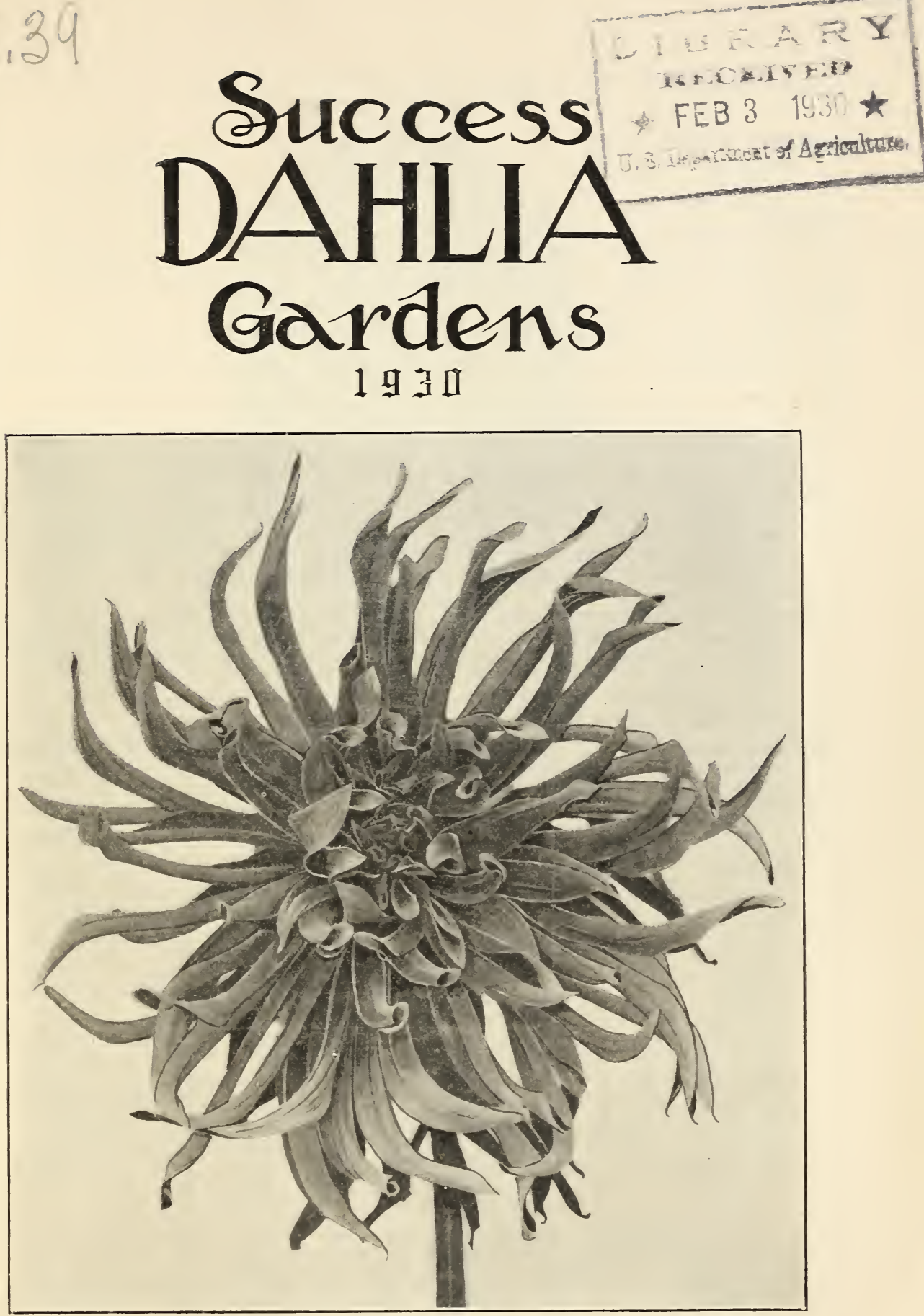

LEVINIA BROOMALL

(See page 5)

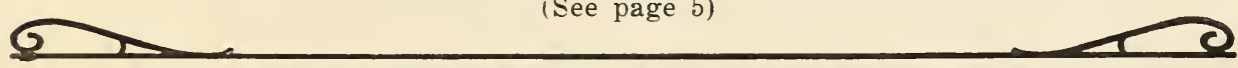

171 FERRY ST LAWRENCE. MASS 


\section{General Information}

TERMS: Remittance with order on or before shipment. Retail orders are delivered prepaid. Please remit by bank draft, Post Office Order, or registered mail. stock sent C. O. D. unless 50 per cent of purchase price accompanies order. Re( Canada or other foreign countries.

Orders are filled avoid disappointment should the variety desired be sold out an order an order complete we will assume no responsibility in excess of purchase price of stock we are unable to fill order on.

SHIPPING: We begin shipping tubers about April 15th unless otherwise desired. Green plants are shipped from May 15 th to June 15 th.

SUBSTITUTION: We never substitute without permission, but suggest you mention a second choice.

CULTURE: Complete instructions for growing Dahlias will be sent with each order.

GUARANTEE: All stock is guaranteed to be true to name and in growing condition upon arrival. If for any reason it is found otherwise please return at once and we will cheerfully replace or refund purchase price if requested to do so.

GREEN PLANTS: Our green plants are all base cuttings, which make stocky, well rooted plants that will grow and produce fine bloom and make good clean tubers. Our plants are grown in a specially built green house for this purpose. They are grown under moderate heat, and at the proper time are hardened off in cold frames. We have shipped green plants to California and they arrived in fine condition

COMNERCIAL GROWERS: We cater to a high class retail trade, but we will allow the usual trade discount on our own introductions on other varieties where our stock will permit, except where prices are net. Write for discount mentioning varieties wanted. We grow many varieties not listed.

SPFCIAL BARGAINS: Collections of 6 named varieties $\$ 5.00$ and $\$ 10.00$. Our selection, all different large blooming kind.

ABbreviations: C., Cactus; H. C., Hybrid Cactus; D., Decorative; P., Peony-flowered; S., Show; H. D., Hybrid Decorative

NOTICE: This list cancels all previous prices.

THE PATH O' FRIENDSHIP

I am proud to be a-tellin'

Of a path (not very wide)

From my neighbor's little dwellin'

To the place where I abide!

It's a path that wasn't laid there

Out of bricks, in pattern neat-

But it's daily bein' made there

By the tread of friendly feet.

It's a gentle, silent token

Of a Friendship warm and true.

That I hope may not be broken

Till our days on earth are through:

It's a sign of hands extended

Wihen the hour of need was nigh-

It's a sign of something splendid,

Something gold can never buy!

You can have your fancy pickets

All around your velvet yard-

You can screen it in with thickets.

You can have a gaite that's barred.

But for me-no fence I'm needin'-

I've a yard that's open wide

To the paths that may be leadin'

From my neighbors, to my side: 


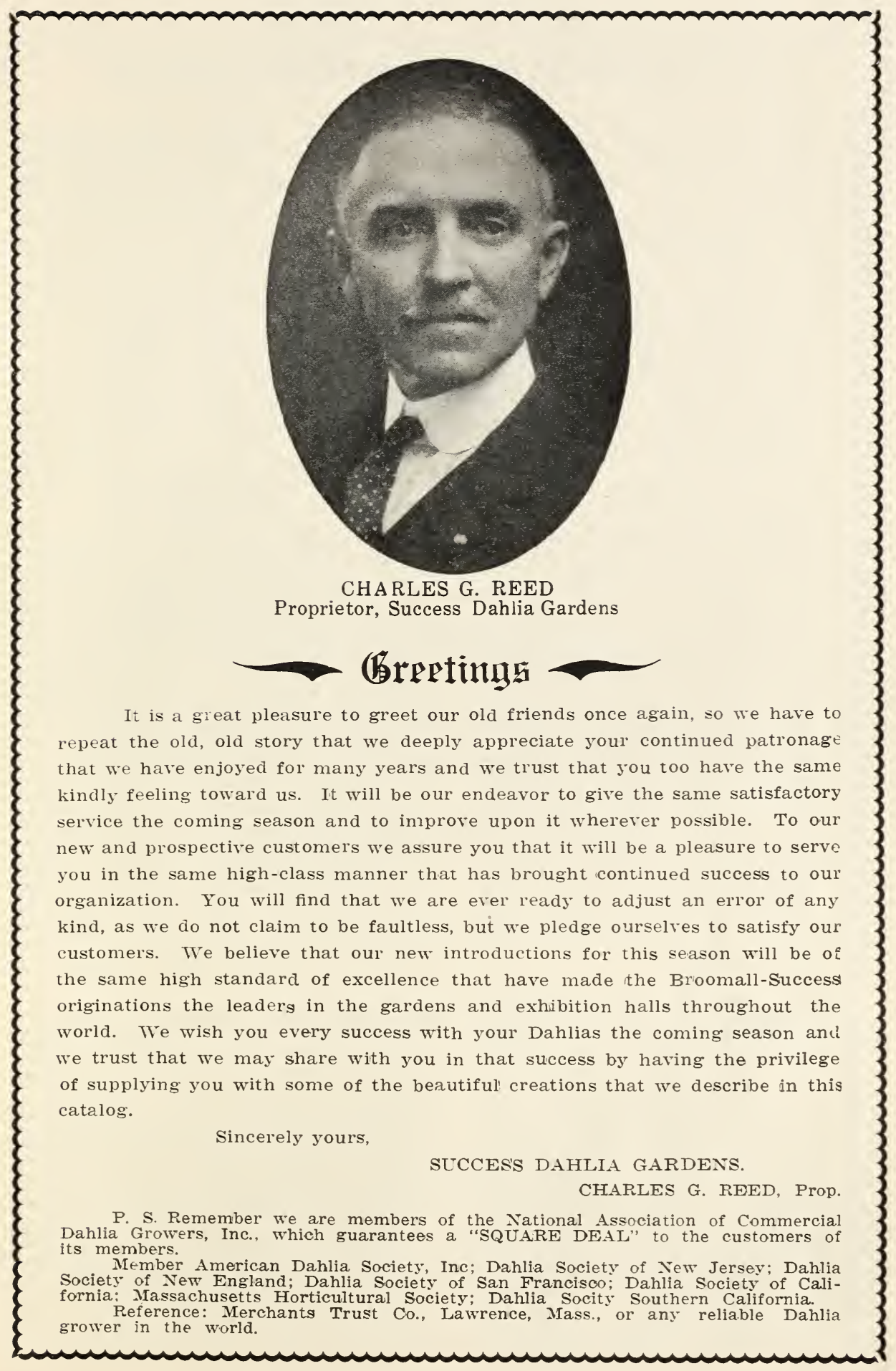




\section{A Message to My Friends.}

Quite a number of my friends and former customers not understanding why they failed to receive my catalog last year, I feel that an explanation will be in order. Owing to failing eyesight and inability to properly attend to my rapidly growing Dahlia business, I disposed of my mailorder business to Mr. Charles G. Reed of the Success Dahlia Gardens, Lawrence, Mass.

All requests for catalogs and information in regard to prices, etc., should be addressed to the Success Dahlia Gardens, Lawrence, Mass., as I have retired from the mailorder business and will issue no more catalogs.

I want to thank my friends for the many favors I have received in the past, and to assure them that they will receive the same careful attention from Mr. Reed as I have endeavored to give in previous years.

I expect to continue my work at the Eagle Rock Dahlia Farm in my efforts to improve the Dahlia and Mr. Reed will have the sole right of introducing the new varieties that I hope to be able to develop.

Sincerely and gratefully yours,

J. J. BROOMALL.

\section{BROOMALL-SUCCESS CELEBRATED ORIGINATIONS FOR 1930}

We take pleasure in presenting the following originations of that master, J. J. Broomall, who has contributed so many rich originations to the Dahlia loving public. Mr. Broomall considers these new creations are of the same high standard perfection as his former introductions except they are very much different and should please his many friends and former customers. We are the exclusive introducers of all $\mathrm{Mr}$. Broomall's future introductions. We would advise ordering early on these new creations. 


\section{BROOMALL-SUCCESS 1929-1930 INTRODUCTIONS}

EAGLE ROCK WONDER (H. C.)-For tremendous size, perfection of form and habit of profuse blooming qualities and vigorous growth, I have seen no equal of vigorous growth, I have seen no equal of in the garden, the color is mars-orange in the to orange-buff with tints of coralpink and coral-red according to Ridgeway's color chart; the general effect being between orange and apricot. This Dahlia sometimes forms a number of adventitious buds on the back of the flowers; so far probably not more than twenty per cent have done this, These buds, reminding one of Brussels sprouts, do not affect the appearance of the front of the flower. They can easily be removed before the main flower is fully developed and it seems to me are caused by the extraordin'ary vigor of the plant, seemingly to give an outlett to its unusual energy. This variety has never yet shown an open center even under the most unfavorable conditions. A monster. Height 5 feet.

Tuber $\$ 25.00$. Plant $\$ 12.50$.

GOLDEN HARVEST ( $H$. C. $)$-A most striking variety, producing enormous blooms of a beautiful sulphur-yellow in color, with no shading. The blooms are held perfectly erect in the best of stems and by disbudding it is possible to grow blooms larger than Siskiyou. The plants are a mass of bloom from early to late in the season. I have never seen such large buds before the petals commence to unfold and reminds one of the enormous exhibition Chrysanthemums, as they open up, only much larger. A winner. Height 3 feet.

Tuber $\$ 15.00$. Plant $\$ 7.50$

LAVINIA BROOMALL-American Cactus - Very large and unusual in form and color. I know of no other Dahlia that is so different even when grown among the very best new varieties. It attracts immediate attention and will be a valuable addition to any first class collection as there is nothing like it. A profuse bloomer and the large blooms are held erect on good stems. Color light orange-yellow to capucine yellow, shaded corral-pink. No description can fully describe this new creation. To grow it will be a joy forever. Stock limited. Heighit 3 feet

Tuber $\$ 15$. Plant $\$ 7.50$.

ROSINA MEHAFFEY (Dec.)-We all admire the large ones and in this new variety we find our want fulfilled to the uttermost. We like good vigorous growers that are insect proof. We have it here. I do not know how large they can be grown if disbudded, but we cut many 9-10-inch off plants not disbudded or pruned. so judge for yourself. Color tyrian-pink. Fine strong stems holding the big bloom erect.

Tuber $\$ 15.00$. Plant $\$ 7.50$

JUNE JUSTICE (Success) (Dec.)-This very unusual colored Dahlia has been the center of attraction in the garden and show-room; the strong growing plant is absolutely insect prolof. It made good at the American Dahlia Society official tria garden at Storrs, Conn., in 1929, which proves that it measures up to the elite of the Dahlia world. It is quite difficult to win a certificate but "June" was one of the outstanding Dahlias throughout the season and received a certificate. Most dark colored Dahlias seem to have a dullness to them but it is just the opposite in this new creation; the trial garden report reads: "A mixture of Rhodmine purple and tyrian rose. No color like it in book. Very brilliant in color." Strong stems hold the very large bloom erect. Height 5 feet. Tuber $\$ 10.00$. Plant $\$ 5.00$.

MRS. EMILIE H. KITSON (Success) (H. C.)-One of the most aitractive Dahlias in our garden as it is always covered with large bloom held erect on the very best of stems. The attractive color combination appeals to our visitors, the inner petals are of Grenadine pink while the outer petals are pale orange-yellow. This origination was awarded a Certificate of Merit at the A D. S. trial garden at Storrs, Conn., in 1929. It has also won the prize for the best Dahlia in show in strong competition. ... Tuber $\$ 7.50$. Plant $\$ 3.50$.

EVELYN MORRIS (Dec.) (Broomali)Here again we have anather new color in this very large decorative and when we say it is a right bright purple we do not give this Dahlia justice. Its tall growing habit with the immense bloom held erect on the finest stems attracts the visitors from a distance. It surely is different. Height 6 feet. Tuber $\$ 10.00$. Plant $\$ 5.00$

GOODNIGHT (Dec.)-We have grown many fine dark colored Dahlias but we find in this variety a monster in size and the rich color of ox-blood red, shaded maroon, is the greatest attraction in the garden and in the show-room. The demand is so great this season, after releasing a few last season, that we cannot fill the demand, and only two to a customer until our supply is exhausted. The price is net on tubers. Tuber $\$ 10.00$. Plant $\$ 5.00$ net.

LILLIAN MILLER (Dec.) (Broomali)A large decorative of fine exhibition form. In color an unusual shade of pomegranitepurple that adds to its beauty. This Dahlia will make a worthwhile addition to any collection where something different is desired. Height 3 feet. A New Jersey grower writes: "12-inch flowers were grown on this variety last season."

Tuber $\$ 7.50$. Plant $\$ 3.50$

LOLETA (Dec.) (Broomali)-Another of those very large finely formed flowers of a shade of mallow - pink that appeals to the visitors. ........ Tuber $\$ 7.50$. Plant $\$ 3.50$.

MAIDEN'S BLUSH (H. D.) (Broomall)This immense decorative, aside from being one of the largest to commend it, is a model for shape and habit of orowth, and, above all its remarkable and distinct color, a very light rose pink or blush. Mr. Broomall refers to it as "one of the most beautiful flowers I ever saw and more like an immense Orchid than a Dahlia." If this Dahlia has any fault it is perhaps a little soft for cutting, says the originator, but he said the same thing about "Aztec Glory," but it is an ideal cut flower in the East. Height 5 feet. Stock very limited. ....... Tuber $\$ 10.00$. Plant $\$ 5.00$

MILDRED BROOKS HOOVER (H. D.) (Broomall)-(Named by request for sisterin-law of President Herbert Hoaver). The 
originator considers this one of the best Dahlias in his gardens ais the color, Spinelred, is so different. A mosst distinct and refined flower, of large size and splendid form. A Dahlita that should be in every first-class collection. Height 4 feet.

Tuber $\$ 10.00$. Plant $\$ 5.00$.

ROSE.ELLEN VARBLE (H.C.) (Broom. ali)-Beautiful is the one word that de- scribes this Dahlia and we consider it one of our very best introductions. In color jt is an entirely new shade of exquisite old rose and coral-pink and was greatly admired by all who saw it. The foliage grows close up to the flower but by disbudding the habit is such that it can be grown with long straight stems. Height 5 feet. Stock limited.

Tuber $\$ 10.00$. Plant $\$ 5.00$.

\section{BALLAY'S DAHLIA GARDENS \\ LOS ALTOS, \\ CALIFORNIA.}

\section{TO OUR PATRONS AND FRIENDS}

We are pleased to announce this year that we have been fortunate in securing Mr. Charles G. Reed of the Success Dahlia Gardens, Lawrence, Massachusetts, to represent us in the Eastern market. Mr. Reed is one of the largest and best known dahlia growers on the Atlantic Seaboard. He has been growing our dahlias and is therefore in position to speak on their merits when grown under Eastern conditions. All orders originating in the territory east of the Mississippi River should be sent direct to Mr. Chas. G. Reed, 171 Ferry St., Lawrence, Mass. Orders from the Pacific Coast and all territory west of the Mississippi should be sent to us as heretofore.

In being relieved of the responsibility of handling the Eastern trade we will have more time to devote to the creation of superior new varieties which we hope to offer you in the near future. In this connection, might add that we have some very fine ones that we hope to be able to release next season.

Yours for more and better dahlias,

$$
\text { C. W. BALLAY. }
$$

\section{EXCLUSIVE EASTERN INTRODUCERS OF C. W. BALLAY'S INTRODUCTIONS FOR 1930}

ALAMO (Dec.)-Rose and gold. A blending of collor in which the two shades are about equally distributed. The effect produced is pleasing and novel. The flower is of good size, deep and well formed, with a straight stem. Plant is fairly tall and blooms freely. Tuber $\$ 5.00$. Plant $\$ 2.50$.

CHARLES G. REED (Dec.)-Purple-red. This is the color in plainest words. Exactly pecunia-red is what an authority on dress matentials called it-a lively shade not far from crimison. Was awarded. First Prize for the best Dahlia of red coloring in the
Palace Hotel Show. This variety is unusually large and is held upright on a perfect stem. Big, broad petals, a deep full center, and the great profusion of bloom have caused sereral of our visitors this year to exclaim that it was the most beautiful Dahlia they had ever seen. Bush is of rather low growtl with the branching habit which makes it ideal for all purposes. We have named this favorite Dahlia of ours for Mr. Charles G. Reed of Lawrence, Mass., one of the foremost Dahlia authorities in the East, who is now marketing our Dahlias to the Eastern trade. Tuber $\$ 15.00$. Plant $\$ 7.50$. 
DOMINICA. (Dec.)-Pure white. So far it seems pure white Dahlias have not kept pace with those of other colors. This white decorative is consistently good and leeps up well through the whole season. The centers are full to the end and its size is maintained. Besides, the many flowers produced are held on strong straight stems which makes it very useful for commercial purposes A white without faults. ......... Tuber $\$ 5.00$. Plant $\$ 2.50$.

DONNA CALIFORNIA (Dec.)-Deep rose pink suffused with lavender. The color is not new but it is doubtless the largest Dahlia by far of that coloring. In fact, it is the largest Dahlia that we have ever grown in our gardens, 12-inch blooms having been produced without effort through a iong period. The flower is not particularly heavy considering its great size, as its even petal formation is loosely arranged rather than solid. The stems are very strong and very long. Te again won the prize for the Best Establisfled Three-year-old at the Palace Hotel. this time with six blooms of this giant Dahlia. ....... Tuber $\$ 15.00$. Plant $\$ 7.50$.

FABIOLA (Dec.)-Pure unshaded larender. This is a large and good Dahlia in the most pleasing shade of lavender we have seen. In November the color was still unchanged and the full broad petaled flowers would still have been suitable for exhibition. The first blooms are rather short-stemmed and should be disbudded accordingly in order to bring the next crop well out of the bushes. A Dahlia that will appeal particularly to those who judge a variety by its late blooms.

Tuber $\$ 5.00$. Plant $\$ 2.50$.

FITZJAMES (Dec.)-Clear amber.. The tall bushes are productive of many large blooms of a color that seems to promote harmony in whatever location it is placed. We have noticed that a bouquet that otherwise seemed quite ordinary was considerably improved by the addition of a couple of blooms of FitzJames. The formation of the flower is just regular enough to be pleasing and the stem is good until late in the season. Tuber $\$ 5.00$. Plant $\$ 2.50$

GAIETY (Dec.)-Paile true pink. A Dahlia somewhat on the style of Jerser's Beauty but of a different color. It is not much larger than the older Dahlia but has the same good stems and similar formation. This variety is free blooming and is very useful and beautiful for interior purposes. .... Tuber $\$ 5.00$. Plant $\$ 2.50$

MAGIC (Hyd. Cac.)-Wine red. This variety is in a class by itself. It is nothing like the maroon hybrids but has a dull silk-like appearance that has not been seen before in Dahlias. The formation is full with well incurved petals and the beauty of the flower is enhanced by a touch of very dark red at the center. Flowers are rery large for a good portion of the season and remain closed late into the fall. Stems are good. Plants are of rather low growth and produce well. ......... Tuber $\$ 10.00$. Plant $\$ 5.00$.
MAYFAIR (Dec.)-Deep old rose with a slight violet suffusion. A big, bold flower. deep and full, and of a very charming color. Long, strong stems that are good early in the season but will droop slighily as the season advances. Plant is of sturdy growth and is always in bloom. This is a variety that attracts a lot of attention and is very handsome whether grotwing or cut.

Tuber $\$ 10.00$. Plant $\$ 5.00$.

NEDRA (Dec.)-Lavender pink. Some Dahlias are at their best in mid-season, others improve when the shorter dass produce slower growth. This Dahlia is at its best in normal weather and can be counted on at show time; in the late fall the centers open. The shade of color is clear and true. The blossom is large and oval shaped with broad heavy petals continuing well to the small pointed center. Stems are strong and grow straight ou of the bushes. An excellent variety and good for every purpose.

Tuber $\$ 10.00$. Plant $\$ 5.00$.

NOVA (Dec.)-Bright old rose of the true old-fashioned shade. There is little variation of color throughout the flower and the tone does not change at different seasons. One could hardly imagine a more fascinating color than the lively richness of this old rose. Large perfecty formed flowers on the strongest upright stems are produced in profusion from early season until frost kills them down. The formation of this entrancing Dahlia is quite regular with the broad heavy petals slightly fluted and folding back well against the stem. It is an excellent cut flower, lasting well, and gracing any occasion. We recommend this variety as an outstanding introduction. .... Tuber $\$ 10.00$. Plant $\$ 5.00$

SULTANA (Dec.)-Bright scarlet shading to a gold center, the brightest, most pleasing color imaginable, of velvet-like texture, reverse of petals also gold. Here is another Dahlia of enormous size, which continues until quite late, but it was at the height of the season that this variety made its special appeal. It is one of those that calls to you from across the field and there are still many people whose favorite color in Dahlias is red. This is one that is hard to beat in its class and has every good quality. .... Tuber $\$ 10.00$. Plant $\$ 5.00$.

VOGUE (Dec.)-Bright salmon, or peach, as some cut flower customers insisted on calling it. This fine medium-sized Dahlia is primarily a cut flower variety. It keeps a week or longer when cut and is of a color that seems especially adapted to that purpose. Best of stems, freedom in blooming, but not very large. A plant in the garden itself looks like a bouquet.

Tuber $\$ 5.00$. Plant $\$ 2.50$. 


\section{We take pleasure in offering for your consideration the following new creations from other originators that have made good:}

THOMAS A. EDISON-This gorgeous new royal purple exhibition decorative, selected and named by permission of the famous electrical wizard, met with his complete approval when viewed at his West Orange estate. The staghorn petal formation, the dark green insect-resisting foliage, the cane stiff stems, and its thrifty growing habit leave nothing to be desired.

Plants only, $\$ 10.00$ Net

GRACE CURLING (Dec.)-We wish every Dahlia grower could see this wonderful Dahlia in bloom. It is a glorious decorative of very large size, imposing and beautiful in form and color. The latter is white at base, then changing to lilac pink and rose Huge broad florets, bluntly tapering and tastefully notched at tips. It requires no disbudding or trimiming to have equally as large bloom at the end of the season as when they first bloom. Perfect stems and they are long, bearing the big bloom well above the foliage. We know of no Dahlia that is more charming than this imported beauty. Stock very limited and only three to a customer.

Tuber $\$ 10.00$. Plant $\$ 5.00$

CORA BUTTERWORTH (Dec.) - This new creation made a decided hit at the New York show in 1929. Color is a rich glistening primrose yellow. Blooms are well formed, petals wavy, center high, and are borne high above foliage.

Tuber $\$ 10.00$. Plant $\$ 5.00$ Net

ANN RUTLEDGE (Dec.)-A glowing cerise, shaded rose, with mallow-pink reverse; the splendid petal formation with just a half curl makes it a real aristocrat. The great depth of bloom combines with a diameter that puts it in the class of largest blooms, and this combined with its canelike stems makes it a Dahlia to be desired by all lovers of the best in Dahlias. The fact that it won the Achievement Medal at the first time of showing stamps it as a Dahlia of exceptional merit and worthy of the name of Abraham Lincoln's sweetheart. ..... Tuber $\$ 10.00$. Plant $\$ 5.00$

PATRICIA JEAN (Dec.)-This Dahlia always excites attention in the garden or show room. The flowers can be grown 10 inches and over without disbudding and the stems are 24-30 inches from the first leaf brack and the flowers are carried erect on the stiff, canelike stems. The color at a distance seems to be perfectly white, but on closer examination shows a straight gray line in the center of the petal. Patricia Jean won the A. D. S. Medal at Seattle and the sweepstakes in the one, two and three-year-old seedlings at San Leandro. California, in 1929. Tuber $\$ 15.00$ Plant $\$ 7.50$

BUCCANEER-A giant cactus and the flowers are carried on equally giant stems. The florets are straight, broad at base but narrow and rapier-like at points. Color a glorious rich crimson-scarlet throughout. A most striking variety in every way.

$$
\text { Tuber } \$ 3.00 \text { Net }
$$

MONMOUTH CHAMPION (Dec.)-Winner of the Michell Miedal at the Red Bank Show for the best undisseminated seedling class. Color xanthine orange; flowers 12 inches and over in diameter, full centered and borne high above the foliage on stiff stems, holding the flowers facing forward.
Plant a strong vigorous grower and widespreading, attaining to an average height of 5 feet. Very prolific.

Plants only, $\$ 5.00$ Net

BERTHA MCLEOD (Dec.)-This is a very distinct Dahlia. At first glance it presents the appearance of two or more tones, but the general effect is lemonchrome.. Flowers average about eight inches in diameter and stand on top of a strong stiff stem above the foliage. Plant is very healthy, and semi-dwarf in habit. Very prolific. Tuber $\$ 5.00$. Plant $\$ 2.50$ Net

AUTUMN GOLD (H. C.)-The color of this large flowered variety is bronze lemonyellow, interspersed with gold. A true hybrid cactus of unusual merit. The flowers are produced through a long season, and are held high above the foliage on long, splender but straight, stiff stems. Plant a strong vigorous grower of excellent habit. Tuber $\$ 10.00$. Plant $\$ 5.00 \mathrm{Net}$

RARITAN RAY (Dec.)-A seedling of Jersey's Beacon, possessing the good habits and traits of that old favorite. Flowers are large to very large, and a true Morocco red in color Plant semi-dwarf, healthy and exceedingly prolific of bloom

Tuber $\$ 5.00$. Plant $\$ 2.50$ Net

LAKE COMO (C.)-In this Dahlia we have a color combination of rare beauty, aramanth-purple, tipped violet. American cactus in type, flowers medium to large. and are held well above the foliage on strong stiff stems.. Plant semi-dwarf in habit. Vigorous growers and very prolific of bloom...T Tuber \$5.00. Plant \$2.50 Net

GOLDEN SCEPTRE (Dec.) - A giant flowered decorative of a clear picric-yellow. possessing a richness seldom seen in yellow flowers. Flowers are produced profusely on a medium tall bush. and are held high above the foliage on long stiff stems. A beautiful Dahlia that should be in every collection. Tuber $\$ 10.00$. Plant $\$ 5.00$ Net

LAKEWOOD (Dec.)-This is one of the must distinct Dahlias in color, and I frankly believe there is nothing like it in commerce. The color is a clear listeran-purple, with seafoam yellow center. A new color in Dahlias. Flowers are medium to large, and borne well above the foliage on strong stiff stems. Plant a strong vigorous grower averaging about $51-2$ feet in height, and quite prolific of perfect bloom of true decorative type. Tuber $\$ 7.50$. Plant $\$ 3.75$ Net

EVA L. QUADLING (Dec.)-Immense full centered blooms of the finest quality. Color, carmine and spectrum blended, back of petals same with pale mauve veining. center nx-blond red. Strong medium-tall bush. Was the sensation at the Cumberland Hotel Show at Bridgeton. N. J. Was also in the First Prize Collection of 12 Best Decoratives at Santa Monica and Los Angeles Shows. Has been grown successfully in many parts of the country.

Tuber $\$ 5.00$ Net. Plant $\$ 2.50$

AMERICAN TRIUMPH-A new cactus origination that that attracted great attention at the New Y.ork show, 1929, and won the American Home Sweepstake in about as hot a class as we have seen. Color is a clear, bright, rich red of intense beauty with no tendency to fade. True type, as 
the long quilled petals are decidedly incurved. the center is always high and full. A grand keeper on the bush or when cut. Tuber $\$ 10.00$. Plant $\$ 5.00$

MARGARET F. WYLIE (Dec.)-The outstanding new Dahlia at Hartford, and almost a new color. A bright vermillion rose-red, with the reverse of each petal a rose-pink and silver. Many of the petals are slightly curled, and the silver tints that show up make the flower very attractive. It is unlike any Dahlia that we know. Placed on the Honor Roll in 1929.

Tuber $\$ 10.00$. Plant $\$ 5.00$

WATCHUNG WONDER (Dec.)-Another sensational Honor Roll Dahlia that is bound to be grown by those who like the best. "This is the richest colored red Dahlia. Not ret disseminated generally, but a magnificent Dahlia in appearance and growing habit. It was a consistent winner in specimen classes during the year, and deserves the rating we have given it in the paragraph above." These are Mr. Derrill $\Pi$. Hart's comments on this variety in the 1929 Honor Roll issue of the American Home Magazine. Plants Only, $\$ 7.50$

CHEMARS EUREKA (Dec.)-A rery charming new white that has received much attention the past season. It is almost pure white with just a touch of lavender at the tips of the center petal. Released last season at $\$ 25.00$ per tuber. Tuber $\$ 10.00$. Plant $\$ 5.00$

KATHLEEN NORRIS (Dec.)-The Wonder Dahlia of the Century. A huge flower of clear pink, borne upright on rigid, long stems. Experts say it is the best pink Dahlia in commerce. A winner everywhere in "Court of Honor Class" for largest and best. It has outclassed all other Dahlias of a similar color in all leading shows for past two years. We have a large stock of this wonder Dahlia.

Tuber $\$ 10.00$. Plant $\$ 5.00$

PACIFIC SUNSHINE (Dec.)-Tisitor will recognize this variety as labeled "Golden Orange" in our garden. It has always been outstanding the past two vears that we have grown it. The originator, Mr. W. E. Trostle, a California grower. thinks quite well of this variety and has used it freely in his prize-winning displays. It is now released for the first time after being awarded a Certificate of Nerit at the A. D. S. trial garden at Storrs, Conn., in 1929. Color, center rose doree rest of petal picric-yellow with marking of rose doree. This gives a glowing effect that fairly gleams when looking at this creation. Flowing habit prolific. It is possible to grow 9-10-inch flowers by disbudding. Good stems.

Tuber $\$ 10.00$ Plant $\$ 5.00$

GOLDEN SONNE (Cactus)-A Holland introduction of intrinsic beauty. It was shown at Baltimore and was one of the outstanding varieties and this was one of the best shows in the East. Won sweepstakes at Elizabeth in the buff, lemon. orange, Specimen Bloom Class. It is a deep flower of clear golden-yellow, shading to soft salmon-rose of the outside petals. The heavy petalage gives the flower its beauty. Good stems and a free bloomer. Placed on the Honor Poll, 1929.

$$
\text { Tuber } \$ 7.50 \text {. Plant } \$ 3.50
$$

DR. ELIAS BARTLEY (Dec.)-An immense, perfect flower of clear, orchid-pink. Mr. Derrill W. Hart has placed this Dahlia on his 1929 Honor Poll so it must be good. $\mathrm{He}$ mentions it winning sweepstakes for two rears in succession as Best Bloom at a quality show. At the New Tork Show, 1.925. it won in the Best Decorative Bloom Class. If $y$ u want something new to win in the "largest in the show class" this monster should help you. It has extreme beauty and size, a fine combination for a modern Dahlia.

Tuber $\$ 10.00$ Net. Plant $\$ 5.00$

EDWARD THOMAS BEDFORD (Dec.)We grew this variety last year through the courtesy of Mr. John Brock, the originator, and believe it or not it was about the biggest and best Dahlia that it has been our privilege of growing. Surely there is no deep purple that can compare with it in size, for this one is a giant and the bloom are held perfectly erect on long cane-like stems, and what a bloomer! Always covered with mammoth flowers. It surely is Mr. Brock's masterpiece and we cannot forget those Brock creations at the New Fork show a few years back, everyone a jewel in itself. Please do not confuse this Dahlia with the old E. T. Bedford. this is a new one and it's a wonder

Tuber $\$ 20.00$. Plant $\$ 10.00$

MISS HILDA BROOK (Dec.) (Success)As a seedling this has been one of our most popular Dahlias in our garden on account of its attractive and unusual color combination. Color a rich golden-buff with each and every petal tipped with the purest white. This variety has never failed to come true. every petal tipped white. It is a large blnom variety held erect on good stems. Released $n-w$ for the first time.

Tuber $\$ 5.00$. Plant $\$ 2.50$

\section{We present the following standard varieties that are leaders in the garden and show room:}

AZTEC GLORY (H, D.)-This immense picric or lemon-yellow is perhaps the most sensational yellow Dahlia of all time. In the show rooms it remains supreme not only in its color but is always considered when the award for the best bloom in the show is being selected by the judges and it often wins this high honor. The mammoth flowers are held erect on the best of stems. It won the Challenge Cup for the best blnom at the Ontario Dahlia Show. 1928. It is a real champion. Largest Dahlia Class winner Madison Square Garden. New Fork. Show, 1929. ..... Tuber $\$ 5.00$. Plant $\$ 2.50$
AMARANTHUS (H. D.)-Amaranth-pink, very large flowers, good stems. Height $2^{1}$ feet. ............ Tuber $\$ 3.50$. Plant $\$ 2.00$

AMBASSADOR ( $H$. C.)-This beautiful Dahlia has always been a prize-winner. The color is a soft vellow center with salmon, amber and pink shadings, gradually deepening towards the tips and outer floral rays. Has won prizes for the largest in the shnw. Sold for $\$ 50.00$ per bulb when introduced. ................. Tuber $\$ 1.00$

AMARILLO GRAND (H. D.)-Light rellow, compared with Sunny South the peials 
are more broad, and the flowers are much larger, in fact they are enormous and are produced in abundance. ...... Tuber $\$ 2.00$

ALICE WHITTIER (H. C.)-Our own introduction that is considered the best yellow hybrid cactus ever introduced. Its record as an exhibition flower is known from coast to coast as it has won the highest award in many exhibitions throughout the entire country. Beautiful, vigorous Dahlia that pleases all. Awarded certificates at three different trial gardens with a high score of 90 points. .......... Tuber $\$ 1.50$

AMAZON (D.)-Bright coral-pink, deeper at the center, and with a suffusion of pale gold on the inner petals. Decidedly decorative in type but not formal. Visitors were greatly attracted by the beautiful coloring and the wealth of bloom. It is a fascinating cut flower and distinctive on the exhibition table.

Tuber $\$ 2.50$

ARDIS (Dec.)-Bluish violet or purple. We have grown it successfully this season and are pleased to have the opportunity of introducing it to the public. The color, which is unusual in Dahlias, is most pleasing and the flower is large, well-formed and held on a good stem.

Tuber $\$ 2.50$

ADALINE WINTER (Dec.)-New. 1930. It is a brilliant vermillion-carmine, has long stems, foliage, is hardy and is most fascinating as a cut flower, remaining dcuble to the end of the season. Tuber $\$ 1.00$

BIG CHIEF (H. D.) (Success)-This is the largest Dahlia that we have introduced having exhibited it only once. Color rich autumn shades, general effect is salmonbuff. Immense flowers are carried erect $\mathrm{n}$ long stiff stems. Tery free bloomers. Height 4 feet .... Tuber $\$ 7.50$. Plant $\$ 3.50$

BETTY IVINS (Exhibition Decorative)Color a rich salmon, overlaid with an amber glow, showing a rosy pink reverse. Petals have that soft glistening gleam, as reflecter in the texture of a rose. For a flower of such size, it has a remarkable stem that holds it perfectly upright. a point which has been noted by many of its =dmirers.

Tuber $\$ 500$

BERENGARIA (D.)-The originators of this Dahlia consider it one of their triumphs in every way and when we saw the immense blooms growing on sturdy plants we cnuld well agree with them. Colors are oranoe at center, to gold at tips, with golden sheen over all ... ............... Tuber $\$ 3.00$

BARBARA WEAR (D.)-The fact that Barbara Wear won at the 1927 exhibition of the Dahlia Society of San Francisco helf at the Palace Hotel, the Doubleday- Page \& Company's Achievement Medal for "the most worthy new Dahlia west of the Rocky IIountains never before exhibited" is in itself a strong recommendation. The color is extremely soft and pleasing. the beautiful flower being a pinkish lavender, shading at the outer ends of the petals to the softest creamiest effect imaginable. The stems are perfectly straight, very long and excesdingly strong.

BETTY BROWNE (D ${ }^{\circ} \mathrm{C}$ )- Seedling of the beautiful pink Glory of Monmouth. Color is spinel-pink, and old rose blend. deen lemon-vellow at base of petals. Flowers full centered and of large size. averaging 10 inches and over in diameter. and 6 to 7 inches in depth. The large well built blooms are borne on stiff stems well above the foliage. Plant is of medium height, wide-spreading, and rigorous constitution. A good Dahlia in every respect.

Tuber $\$ 7.50$. Plant $\$ 3.50$

COLOR SERGEANT (D.)-This is a very striking Dahlia both in form and color, and one which is always much admired. It is pure in color, being a rich deep salmonbronze. It has splendid habits, being a clean, upright grower, and the large flowers are borne on perfect stems. Tuber $\$ 3.00$

CORINGA (H. D.)-Described as capucine yellow, shaded cornelian-red (Ridgerray), the rich coppery-orange color of this Dahlia attracter more attention in our Boston display than any other Dahlia. There is no other orange-colored Dahlia that can compare with this creation as the color is so vivid that it speaks for itself. Mr. Derrill WV. Hart placed this beautiful Dahlia on the Roll of Honor in 1928. If you are seeking something entirely different from any other Dahlia we highly recommend "Coringa" to you. Tuber $\$ 5.00$. Plant $\$ 2.50$

CREOLE (Dec.)-Deep velvety maroon. Verv dark Dahlias are always in demand. In Creole we have a very large Dahlia of deepest coloring but equally as striking is the very novel formation. The numerous petals are quite long and broad and pointed at the tips with an inclination to roll backward. There is a slight twirl to each petal which lends a similar effect to the whole flower. The centers are full and good until very late and the blooms are freely produced on good stems. ....... Tuber $\$ 7.50$

COUNT MANCINI (P.) - Yellow-buff, opening a yellow. Which soon becomes overlaid with a flush of thin red giving a buff tone. Under artificial light the yellow is lost and the color appears to be a soft pink. Thick blossom with wide petals: profuse bloomer. ................ Tuber $\$ 1.50$

CHANG (Dec.)-Burnished copper and gold-of oriental blending and lustre which is unmistakably associated with the Far East. The reddish-copper tone, which is very prominent in the earlier flowers, is largely displaced $b y$ the gold coloring in the late season. The gorgeous bloom is very full with great depth and massive in size- "Chang" meaning "elephant" in the Siamese language. Grows on top of a long and extra strong stem on a rather tall bush which bears the great blossoms freely.

Tuber $\$ 5.00$

CAMILLE (Amer. C.)-Flesh-pink shading to cream. Rather coarse petals. Good stem. Gnod variety of this type for a sunny climate. ............. Tuber $\$ 2.50$

CHARLEMAGNE (Dec.)-Deep canaryyellow. A very large flower with broad, heavy, loose petals, the broad petals continuing to the very center, producing a deep flower of rose-like formation. The bloom is held absolutely upright on a very strong stem. The plant is low growing and free blooming. .......... Tuber $\$ 2.50$

CONQUISTADOR (H. C.)-Soft creamy rellow shading to a glowing pink at the base of the petals. The pink coloring is very pronounced and gives to the flower the appearance of heing illuminated from within. This is a Dahlia built on a massive 
plan. The plant is extraordinarily tall and the flowers can be cut with 4 -foot stems. The bloom is in proportion, being regular, rather coarse-petaled, broad and deep. Moreover, the texture of the flower is of the same vigorous quality, not being easily soiler by wind, sun or moisture. Beautiful, vigorous, hardy-a "best Dahlia in the show" variety. ... Tuber $\$ 7.50$. Plant $\$ 3.50$

DERRILL W. Hart (Dec.)-Considered by many growers to be one of Mr. Broomall's greatest originations; anyway it was good enough to win many high honors in the keenest competition and found a place on the Roll of Honor by Mr. Derrill W. Hart. Color, capucine-yellow, shading to grenadine-red, in cold weather almost a copper color. The large well-formed bloom are held erect on long, stiff stems. Universally admired by all who saw it.

Tuber $\$ 7.50$. Plant $\$ 2.50$

DERBY (Dec.)-Pale bluish lavender throughout, almost the shade of the forget-me-not. There is unusual character about this perpetual blooming variety with its crisp, light green foliage. It is difficult to make descriptions varied and yet not constantly repeat that the formation of the flower is of the best type and the stems long, strong and straight. .... Tuber $\$ 2.50$

DAPHNE (H. C.)-Bright true pink, sometimes having a touch of a slightly deeper shade at the center. The enormous shaggy flower is of the true hylbrid cactus formation. The many blooms, with tight, perfect centers, are held on stout, straight otems high above the foliage. Its rare coloring and exquisite beauty has immediately made it a favorite. The Certificate of Merit, offered at the Palace Hotel Show, in place of the Gold Medal of previous years, for the best established three-yearold variety, was awarded to six matchless blooms of this delightful pink, so Daphne starts on its career in the rank of a Gold Medal Dahlia. ...... Tuber $\$ 7.50$. Plant $\$ 3.50$

DR. JOHN H. CARMAN (Dec.) -A large, deep, broad-petaled tyrian-rose flower, tipped petunia and silver, of largest size held erect on stiff, heavy stems. A large leaf variety which means insect resisting plant. .......... Tuber $\$ 7.50$. Plant $\$ 3.50$

EAGLE ROCK WONDER-(See new varieties in front of Catalog.)

EAGLE ROCK GEM-Maize-yellow, shaded orient pink. This is certainly the finest shaped strong-stemmed Cactus Dahlia yet produced. Its form is much finer than Ambassador, and the color is very unusual and pleasing; the habit is good, the flowers always standing perfectly erect. Height feet. .......... Tuber $\$ 7.50$. Plant $\$ 3.50$

EULALIA (H. D.)-The ground color is a rich jersey cream, suffused with peachpink, a very attractive variety. The blossoms are large and supported on good stems. ................... Tuber $\$ 2.00$

EAGLE ROCK BEAUTY (H. D.)-A more beautiful combination of pink and cream than displayed in this glorious creation would be difficult to imagine. It is in a class by itself, and unanimously admired by all who saw it. It is vigorous in growth, with good habit, and strong stems holding the immense blooms erect, which are full to the center, and produced in abundance until frost. ................ Tuber $\$ 2.50$

EAGLE ROCK SUNSHINE (C.)-Rich vellow of a deeper shade than Sunny South The flowers are large and held perfectly erect on good stems. Winner of many prizes for best in show. ...... Tuber $\$ 2.50$

EAGLE ROCK JEWEL ( $H$. C. $)$-Cream overlaid cameo-pink (shell pink). I consider this the most beautiful color in any Dahlia I have seen. The large flowers are borne on strong stems. It is a vigorous grower and a free bloomer.

Tuber $\$ 7.50$. Plant $\$ 3.50$

EVELYN MORRIS-(See new varieties.)

EVENING GLOW (H. C.)-Pinkish copper with yellow shadings. This is another Dahlia of exquisite coloring that is a pleasure in the garden and good for all purposes. In frankness we must admit that some of the blooms have a tendency to show a felv curling petals toward the centre.

Tuber $\$ 2.50$

EDNA FERBER-An outstanding Dahlia in every garden and show room. This beautiful Hybrid Cactus won many prizes for the best flower in the show. Color a glistening coral. shading to old gold at base of petals. Petals curl and twist, making it a very attractive flower. Medium habit of growth, dark green foliage. ....Tuber $\$ 3.00$

ELITE GLORY (D.)-It is a monster flower of a brilliant rich, red color with no shadings, held perfectly erect on stiff stems. Another of those beauties that the visitors rave about. ......... Tuber $\$ 2.50$

EVENING EXPRESS (D.)-This is a new California Dahlia that should be grown by those who delight in using Dahlias for exhibition basket displays and house decorations as it is a mass of bloom throughout the season. The bloom average seven to eight inches, carried erect on very long stiff stems. The color is quite new in Dahlias-royal purple with a silvery reverse which adds to its beauty.

Tuber $\$ 2.50$

FAIR ELAINE (H. C.)-Delicate old rose. An extra good variety that closely resembles the American cactus type in formation. 'The "pink Ambassador" we called it before it was named, although the petals are considerably more incurved than those of the older variety. For true beauty it is hard to surpass and the quantity of good flowers produced is the greatest we have seen; not that it is one of those varieties that requires a lot of disbudding, for it is quite the opposite, but the numerous branches, both upper and lower, all produce good flowers until the very end of the season. ..................... Tuber $\$ 7.50$

FORT WASHINGTON (D)-Here is a Dahlia that can and has won many prizes of the largest in the show. Very seldom less than 10 inches without forcing. The larger flowers are held perfectly erect on long cane stiff stems. Winner of many prizes in all classes for decoratives. Has size, refinement, a free bloomer, and the color is a most charming deep maroon.

Tuber $\$ 3.00$ 


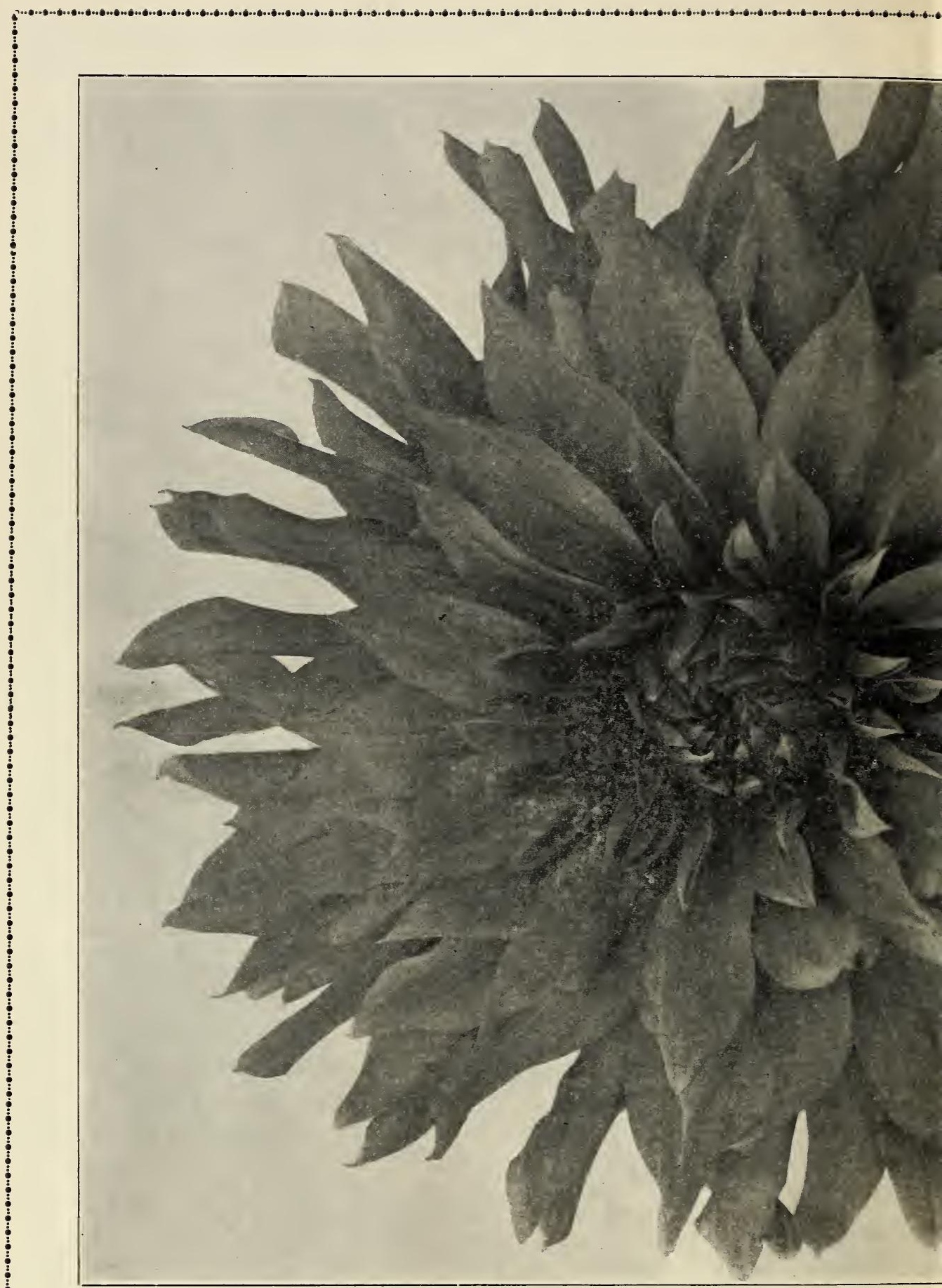



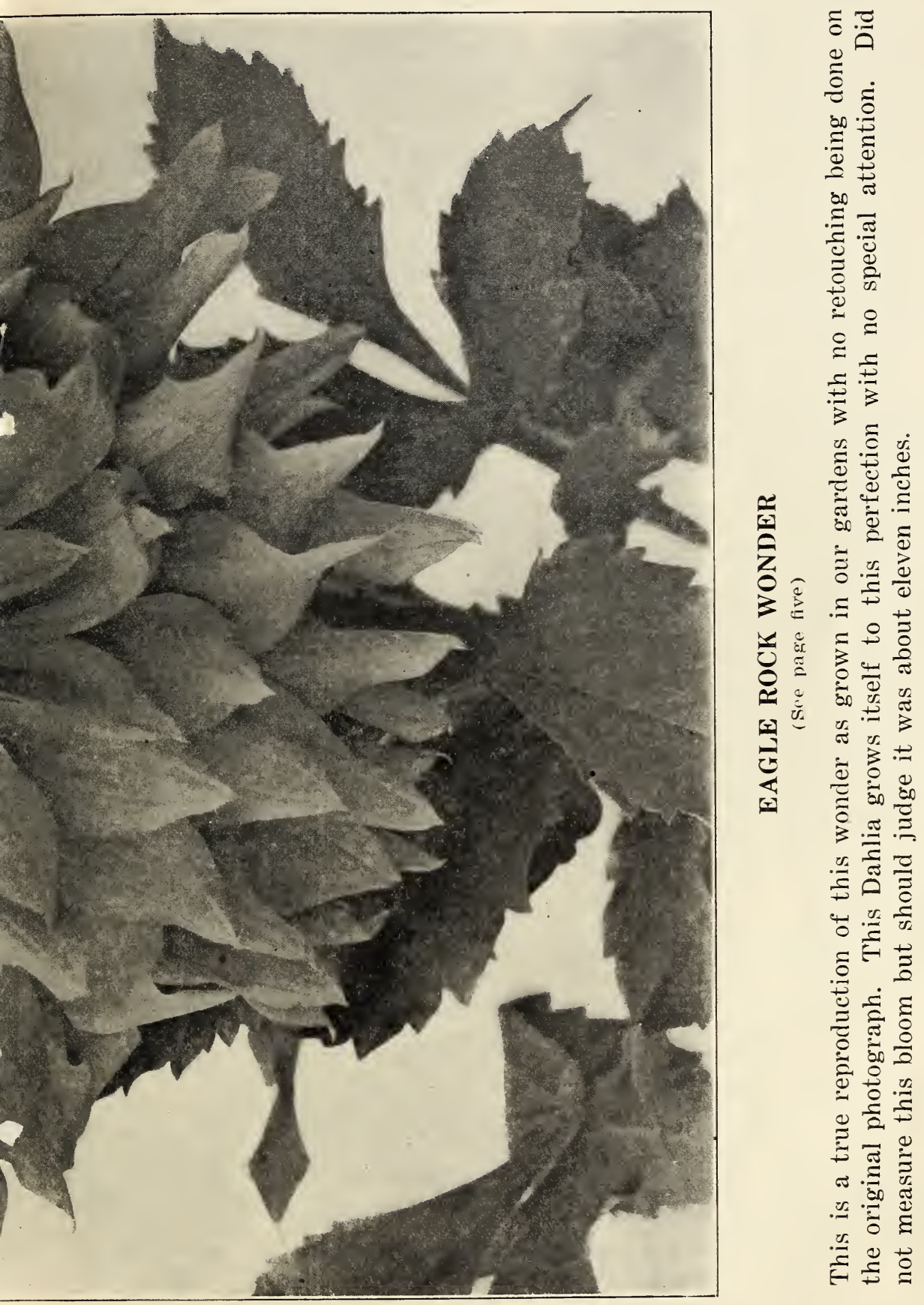
FORT MONMOUTH (H. C.)-One of the giants of the Dahlia world. The color is a rich crimson maroon (some say it is a rich claret), with a brightness unusual in the darker tones, and just a faint tinge of bluish violet at tips of petals. The flowers have long narrow petals, are well formed. full centered, of true hybrid cactus type, and of enormous size, attaining to a diameter of full 13 inches, and are borne on long stiff stems high above the foilage, and look you right in the face. Winning many prizes for best in show.

Tuber $\$ 2.50$. Plant $\$ 3.50$

FLORADORA (Dec.)-Bright apricot. We believe this is a seedling of our well known prize-winner, "Jove," although its habits are considerably different and the flower even larger. The rich coloring makes a special appeal and the formation is interesting in that the petals are unusually lone and slightly recurved. It is a loosely formed flower rather than a heary one and its depth is sufficient to balance its substantial diameter. Free blooming and of medium height .........Tuber $\$ 7.50$. Plant $\$ 3.50$

FORDHOOK VICTORY-Giant flowers, well formed, and carried on strong sturdy stems. The color is a rich shade of tyrianrose. The petals are well placed and of substantial texture. ........... Tuber $\$ 2.00$

FIRE CHIEF (Dec)-This is the best scarlet Dahlia that we have seen, and our opinion is shared by many of the better growers who have visited our gardens. Certificates by the A. D. S. and the Dahlia Society of New Jersey at their trial gardens. Flowering habit profuse. Flowers average 8 inches without disbudding. Stiff stems....Tuber $\$ 5.00$. Plant $\$ 2.50$

FORTUNA (Dec.)-Bright rose pink. at different seasons rarying in intensity of coloring, the last flowers begin of a peculiar deep rose tint. This variety is of exceptional size, very deep and heavy, with a stem sufficiently strong to hold it up proudly under all conditions. The heary texture of the petals, slightly crinkled, gives the flowers an unusual waxy appearance and contributes to their excellent keeping quality both in the garden and when cut Never fades in the sunshine.. Tuber $\$ 5.00$

GOODNIGHT.-(See new varieties in front of catolog).

GOLDEN DREAM (Dec.)-Another of our originations. High score A. D. S. trial garden, 1926. Certificated by the Dahlia Society of New Jersey, also winning first prize everywhere it has been exhibited. Color Storutian yellow and a golden shoen or lustre, reverse Brazil red. Long stiff stems. It surely is a Golden Dream.

Tuber $\$ 5.00$. Plant $\$ 2.50$

GRACE RICORDS-A decided outstanding novelty for 1929. This decorative would have probably won over Kathleen Norris had it not been for storm injury when exhibited at the Camden Show as it was a very close second and so different from anything else in form and color. Flowers are large with full, high centres, tipped and suffused lavender on a white ground. petals numerous and decidedly cleft. giving the flower an artistic formation. Bush a tall, open and strong grower.

Tuber $\$ 10.00$. Plant $\$ 5.00$

HARRY MAYER (D)-It's different. The large bloom often were 10 inches and over and carried facing perfectly erect looking you straight in the eye, and you simply have to stop and admire it. The color is very attractive, pale rosalane purple. The habits of the plant are splendid, with that very dark green foilage we all so much admire, with stems carrying the massive flowers erect, high above the foilage. If you want the best don't pass this one.

Tuber $\$ 4.00$. Plant $\$ 2.00$

HATHOR-A decorative of vivid Oriental coloring. The predominating color is flame -not red, but verging on deep crimson, orange, and all those colors seen in glowing embers. The formation is always perfect and the stem exceptionally fine and stiff, so the large bloom looks one squarely in the face. ................ Tuber $\$ 2.50$

IDA PERKINS (D)-Beautiful white heavy blossom with cream colored centre, excellent long stems. A very strong grower; blooms spread about eight inches with incurved petals. Bushes about five feet high. Winner of the Garden and Home Builder Sweepstakes at Boston 192\%.

Tuber $\$ 5.00$. Plant $\$ 2.50$

JANE COWL-This magnificent decorative was without doubt the outstanding Dahlia that has been produced in the East since Jersey Beauty. Te say this after growing this Dahlia the past season and upon its record in the show room. It would be impossible to list its winnings as we are continually hearing of where it won for the best in the show. Mr. Derrill $\pi$. Hart in his Roll of Honor report in the American Home is as follows:

'Jane Cowl was the outstanding Dahlia in every show room. It would be impossible to enumerate the prizes won by this grand flower. Next to Jersey's Beauty we believe that Jane Cowl has the best record of any other variety introduced . It ranks with the immortals of the Dahlia world." The plants are always covered with immense bloom held perfectly erect on long stiff stems and seem to be insect-proof. Color a glistening bronzy buff and old gold blending to a deeper shade toward the centre of the flower, reverse of petals a pale flesh color, giving the flower as a whole. a warm glow. We have a fine stock of this wonderful Dahlia. . Tuber $\$ 7.50$. Plant $\$ 3.50$

JACK O'LANTERN (Dec)-Te released a few tubers of this variety last spring and the reports we have received lead us to believe it was one of the best varieties. Scored 87 at the trial garden of the Dahlia Socieiy of New Jersey. Color, scarlet with reverese picric vellow, finished flower is scarlet centre with crown of empire vellow. Fine stems, profuse bloomer. Stock limited.

Tuber $\$ 2.50$

JOVE (Dec.)-Bronze pink. Pink or Salmon is the predominant color with the brorze coloring somewhat accented toward the center. The flower is very large and can be grown as the largest Dahlia in the show, 10 -inch blooms being common under ordinary field culture. The stem is the best possible, being long. strong and straight. Our row of this Dahlia attracted more attention than anything else in the garden this season. Has everything to make it first-class variety. ...........Tuber $\$ 3.50$

KEMP'S VIOLET WONDER-The best violet colored Dahlia to date. The predominating color of this great Dahlia is a rich 
napthaline violet. with an underlying tone of rosal purple. With bluish lavender reverse. Flowers are as nearly perfect in form as possible: cf true decorative type, and of massive proportions. attaining to a diameter of 10 inches and over. and to a depth of 6 to $\bar{i}$ inches. and are borne on stiff stems 10 to 14 inches above tho foliage.

Tuber $\$ 7.50$. Plant $\$ 3.50$

KIWANIAN (Dec.)-Bright relvety scarlet. This Dahlia has all the earmarks of a "top-notcher." and we think in it is realized the long sought after bright red decorative. The bloom is very full and deep. the petals are unusually broad and artistically waved and curled. The centre is verr full and of that unusual formation that oniy a very broad-retaled Dahlia can have. Plant is of medium height and flomer is held upright on the stem. ....Tuber $\$ 3.50$

KENDAL GLORY (New 1930)-At the American Dahlia Society Trial Ground at Storrs, Conn. Lnder very difficult c nd:tions at these grounds it scored $\$ 3$. and on one of the judges' cards the significant comment was made "It's good." It is a truCactus varietr whose entire blocm is rose red. It lasts about three meeks on the stalk and during the last week a golden sheen developes on the entire bloom. giving it a most gorgeous appearance. It has good long stems, medium heary in size. with flow rs 6 to 8 inches: depth 3 inches. The nlant 5 feet. It is a free bloom 4 . The huge spidery bloom holds a tight full center from early until late season.. Tuber $\$ 7.50$

LEMONADE-Fellom Dahlias are becoming very plentiful, but this one attracted a great deal of attention in the field and on the exhibition table on account of its size and beauty. Clear lemon rellow. stiff upright stems, good habit of grnwth and an excellent keeper wh $=n$ cut. Tuber $\$ 2.50$

LA FRANCE (Dec.)-Pale rose pink. Tre do not claim this Dahlia is exactly the color of the rose of that name. but it is suggestive of it, and at certain times. very much s). The blooms are large and very regularly formed. In the garden of one of our friends who fertilizes his plants heavily. not caring about his crop of tubers. the large plants and blossoms of this Dahlia were as handsome as anvthing in his magnificent chllection. ..................... Tuber $\$ 3.50$

LA RODA (D.)-This beautiful Dahlia has improved with age and has been placed on the Poll of Honor by MI. Derrill Hart. The very large silvery rose-pink. wellformed flowers are held erect on very long stiff stems and the plants are just corered with bloom all the season. The original price of this Dahlia was $\$ 50.00$ per tuber and was worth every $c \in n t$ but we are now offering it within the reach of all growers.

Tuber $\$ 7.50$. Plant $\$ 3.50$.

LA GOLONDRINA (H. D.)-Silvery white shaded phlox purple. the general effect being a light lavender, very large flowers of distinct and pleasing shape. held well abov the foliage on good stems. Height 4 feet.

Tuber $\$ 3.00$

MRS. SHIRLEY SHAW (Dec.) - OX blood red shaded maroon. this magnificent flower sometimes has a tendencr to come with crooked stems. but notwithstanding this fact was more univorsally admired than any Dahlia in our gardens. The monderful dark rich color and immense size capture every one. This Dahlia nust be seen to be ajpreciated as it is impossible to describe the beautiful rich blendings from almost black to nearly a scarlet on each petal. It alsi found its place among the elite of the Dallia world on the Roll of Honor for 192S. It is a real joy to grow a Dahlia like "Mrs. Shirley Shat." Tuber $\$ 7.50$. Plant $\$ 3.50$

MARMION (D.)-This flower is of enormous size and great depth. The long canelike stems hold the huge blooms erect. Color is pure golden yellow with bronze suffusion on reverse of petals. Form is perfect, and early and late the sturdy bushes with their hearr, shining dark green foliage are covered with blooms. Tuber $\$ 2.50$

MILDRED BROOKS HOOVER-(See neTs varieties in front of catalog).

MARIAN BROOMALL (H. D.)-Pink and white. descendant of Gladys Sherwood. it is more Cactus in shape and better stems and habit, a beautiful flomer. Tuber $\$ 2.00$

MARLEAU (H. D.)-Pinard yellow, shaded capucine orange, general effect being salmon-buff. large flowers on long stems. very free flowering. ......... Tuber $\$ 2.50$

MRS. FRANCIS BULLARD (P.)-Beautiful light pink. flowers of immense size. and borne on rather short but strong stems. in the greatest profusion. the bloom are very deep and full for a peony. Tuber $\$ 2.00$

MAIDEN'S BLUSH-(See new rarietie: in front of catalog).

MY MARYLAND-This exhibition bybrid cactus is of a decidedly unique coloring a blending of unusually delicate pink with the faintest suggestion of lavender. the pointed petals whorl and twist in such a manner as to blend the two colors. There are pinks and there are lavenders, but this flower is in a color class of its own. Excellent stems and leathery foliage. Awarded the Martland Dahlia Societr's gold medal for the best undisseminated seedling exhibited at the exhibition of the New Jersey Dahlia Society in Atlantic City. hence its name Also awarded the Garden and Home Builder's Achievement medal. First prize at A. D. S. show in New Tork for bes undisseminated hybrid cactus. Certificate of Merit A. D. S., at Storrs.

Tuber $\$ 7.50$. Plant $\$ 3.50$

MADAME LA ROSE (Dec.)-Rose-red. $X$ t so different from the red of the Hadley rose with perhaps a suggestion of celise. It is certianly a delightful Dahlia because of the color. and the sliape which is perfect in every way is oval and full. However, the branches grow laterally, and while this habit does not interfere with its use for cut flower purposes. some people do not like this tendency in a garden variety. Personally we think this is one of our most charming Dahlias and believe most of you will agree. ........ Tuber $\$ 7.50$. Plant $\$ 3.50$

MOTHER MACHREE (Dec.)-Cream or ivory white with a touch of pink at the center. "Something entirely new." a wellknown authority on Dahlias said. The color 
is surely very much out of the ordinary and the great big deep flowers on tall sialks are outstanding in the Dahlia patch. We have watched this variety carefully fur four years. There were no faults apparent except that this season it would occasionaily throw an open centered flower, due we think to the unusually cool weather. We are mentioning this fact as it is our policy. as we say to our visitors, to tell "the bad along with the good.

\section{Tuber $\$ 10.00$. Plant $\$ 5.00$}

MYRTLE MCBRIDE (H. C.)-Deep dull old rose suffused evenly throughout the flower with dull gold. Tremendously large full flower of truest hybrid cactus type. The rather low bushes are always laden with good blooms on sufficiently long stems. Petal formation is unusual in that there is a tendency to broaden at the tip and twist and curl forward in such a manner as to product an exceedingly nnvel effect.

Tuber $\$ 3.50$

MARTHA KEMP (H. D.)-This is a very refined and a beautiful Dahlia. The color is a warm buff, shading to apricot-vellow at base of petals. The flower is full eight inches in diameter and six inches in $d p t h$. One of the most lasting Dahlias I know, the blooms frequently remaining in good condition a week or longer after they are full bloom. Never sheds its petals, neither when left on the plant or when cut. Prolific bloomer, and a bountiful producer of tubers. ................... Tuber $\$ 10.00$

MRS. WM. A. EVANS (Dec.)-Tery large bright yellow that attracts those who like sturdy plants with very dark green foliage, the kind that makes good in any garden. You will like this one and it's new.

Tuber $\$ 2.50$

MABEL LAWRENCE-A grand Dahlia. It is or enormous size yet notwithstanding this its great weight the giant stems carry the blooms erect. As well as being magnificent in size the flowers are beautifully formed and perfectly circular in outline. Color deep crimson-scarlet throughout.

Tuber $\$ 3.00$. Plant $\$ 1.50$

NETAWAKA (H. D.)-Orange yellow base shading to jasper-red, reverse of petals bright carmine. The petals are twisted so that the reverse color is very much in evidence, the large flowers are borne on good stems, very distinct and pleasing both in form and unusual coloring. Height 5 feet. .... Tuber $\$ 7.50$. Plant $\$ 3.50$

NANCY SUE LANG (H. D.)-Immense star-like flowers, red-tipped gold, larger and stronger grower than Mrs. E. L Lindsey, habit of plant is dwarf and very robust. A flower that attracts immediate attention. ................. Tuber $\$ 2.50$

NORDIC (H. C.)-Light copper with a light rose reverse and slightly suffused with rose. The blooms of this variety are of enormous size, which is especially noticeable because of the long, narrow, incurved petal formation, giving the impression of a wonderful American cactus, from which class it is not far removed. The plant is a tall. robust grower, holding the flowers straight upon long leafless stems. During the four years it has been on trial we have been able to discover no faults. One of the very best ........ Tuber $\$ 5.00$. Plant $\$ 2.50$

ORANGE GOLD (H. C.)-Rich orange- yellow, very attractive color that attracted much attention, medium large, good free-

blooming habit. ............ Tuber $\$ 1.50$

PEGGY ROLLAND (D.)-The joy of growing Dahlias is to grow something different, something the visitors talk about, and above all something you can stand back of when you say to a fellow grower. "It's good." Peggy Rolland is a mighty fine Dahlia, good stiff stems, very dark insect-proof foliage, and the color is unusual yellow with every petal tipped with a delicate shade of red. The blending of these colors makes a most remarkable coloring in a Dahlia. This Dahlia made quite a hit in the Boston Dahlia show in our commercial display. ...... Tuber $\$ 1.50$

PAUL REVERE (D.)-This is one of the best red Dahlias ever introduced. A well known commercial grower in New Jersey called it a 100 per cent Dahlia, fine stem, color is a dazzling bright red. Tuber $\$ 2.00$

PRIMULA REX (D.)-Very light cream of primrose color. I regard this as one of the best decorative Dahlias in existence, the flowers are immense with every good quality, certainly far ahead of anything in its class and color. This variety was highly spoken of in the New York Botanical Gardens. .................... Tuber $\$ 2.00$

PRIDE OF FORT MORGAN-This giant red decorative was introduced last season. It is a wonderful Dahlia and proved the center of attraction of our Dahlia Garden. Stock which we grew the past season proves the claims of its introducer that it is one of the largest and best red decoratives of the Dahlia world. Color, a most intense red. Plant, a sturdy grower. Stems, medium length, holding the flower erect. Height 4 feet. ..................... Tuber $\$ 2.00$

QUEEN OF THE GARDEN BEAUTIFUL (D.) - "A flower that fulfills the dream of Dahlia lovers." This is the way Mr. F. C. Burns described this beautiful Dahlia Winning the celebrated Samuel W. Heller prize at the San Francisco Dahlia Show for the most meritorious Dahlia in the show. It is one of the very largest Dahlias that grows, measuring from nine to 12 inches across and five or six inches deep, grown without forcing. The stems are as stiff as a cane and carry the large bloom perfectly erect and it is a wonderful keeper. Color is a pleasing primrose yellow. The judges scored this Dahlia 94 at the San Francisco show. We have a fine stock of this variety. ............... Tuber $\$ 2.00$

ROSE ELLEN VARABLE-(See new varieties in front of catalog.)

R I CHELIE U-I will simply describe "Richelieu" as a decorative Dahlia of the deep velvety red of the old Jack rose. (Ridgeway's Color Chart: Phlox-purple.) Sturdy bushes with angles to the strong straight stems. As many as seven eightinch flowers have been cut at one time from a bush. With forcing and disbudding larger flowers can be had....... Tuber $\$ 7.50$

RAVEN (H. C.)-Maroon. We do not mean to imply that this "Dahlia is as black as a raven's wing," but the color is maroon slightly blended with purple or cerise-very dark and beautiful. The early flowers are enormous and later on, if all branches are allowed to bud and bloom, the flowers are so numerous as to fairly cover the bush. 
Plants are of medium height and stems very good. ............... Tuber $\$ 3.50$

ROSE FALLON-A truly magnificent decorative of pleasing shades of amber, russet and salmon. The formation is perfect, and the stems are excellent. The foliage of this beautiful variety is very dark and handsome. Rose Fallon is a wonderful keeper, and lasts for days when cut. This Dahlia can easily be shown in the largest bloom class. ......... Tuber $\$ 2.50$

SPOTTSWOOD BEAUTY (D.)-This is one of the most beautiful and one of the best pink Dahlias ever introduced. The color is a clear Chatenay pink, with a slight shading of lemon yellow at base of petals. Flowers are seven to eight inches in diameter, and of great depth, and are borne on long cane-like stems high above the foliage. A beautiful Dahlia that should be in every high class collection.

Tuber $\$ 5.00$. Plant $\$ 2.50$

SAN JOSE (P.)-Purplish-crimson or bright reddish-cerise. We are unable from the color chart to determine the exact color. "Spectacular' 'is the word especially fitted to describe this incomparable peony. Many blooms were a foot across and so brilliantly colored as to truly be a spectacle. The broad petals combined with the most numerous small circling petals around the well pollinated center completed a flower of the most perfect type of peony Dahlia. This variety was outstanding in our display at San Jose which won the first prize for the best commercial exhibit. ................. Tuber $\$ 5.00$

SALEM PRIDE-Very large flower of most attractive color combination, front of petals rhodamine-purple streaked with white and most clear white at tips, hidden center transparent yellow-green. Flowering habit prolific. This is a good one. It's different. ....... Tuber $\$ 7.50$. Plant $\$ 3.50$

SAN CLEMENTE (D.)-San Clemente took first prize for the best established three-year at the California Dahlia Show, Santa Monica, Calif., and for the best established three-year seedling at the Southern California Dahlia Society's Show at Los Angeles. Also winner of first prize for best seedling class open to all and second prize for best Dahlia in show. It is very difficult to describe the color of San Clemente as it is a distinct new break in coloring, being a rich brilliant rose color. It can be easily grown 11 to 12 inches, from beginning of season to the end. The size and color, however, are by no means the best features of this Dahlia as it has a perfect stem, fine foliage, and bears a profusion of bloom from the first of july. to the middle of November. Last, and by no means least, it is an excellent keeper.

Tuber $\$ 3.00$

SCARLET TANAGER (D.)-New introduction that is different as the color is an entirely new shade of richest scarlet. One of the greatest assets of this Dahlia is its habit of growth, having a heavy, deep green foliage with an ideal stiff stem, holding the flower well above the foliage. A profuse bloomer of uniformly large bloom. A prize-winner every time exhibited. One of the outstanding Dahlias in our garden last season. Tuber $\$ 5.00$. Plant $\$ 2.54$
THE BANDIT-That brilliant scarlet and yellow hybrid cactus that wins everywhere. What other Dahlia has a better record at the trial gardens and in the show room? Award of Merit at the trial gardens at New Brunswick, N. J., and Storrs, Conn., 1925, Northwestern trial gardens and the trial gardens of the Dahlia Society of California 1926. ............ Tuber $\$ 2.00$

THOS. HAY -A giant in very truth, of clear lilac color throughout, flowers deep, full and massive, with broad florets bluntly pointed. The stems carry the huge flowers with ease, and the plants flower with surprising freedom. This variety is almost identical in every way (except for its lilac color) to the now famous "Berengaria." One of the best Dahlias in our garden. .......... Tuber $\$ 3.00$. Plant $\$ 1.50$

TROPHY (Dec.)-Bright old gold. Dainty flowers of good size with slightly reflexed petals. Especially good for cutting on account of the color, stem and keeping qualities. In late November the flowers were quite as good as the first blooms in July.

Tuber $\$ 2.50$

THE WORLD (Dec.)-This wonderful new Dahlia was selected at the A. D. S. Show in New York by Mr. J. D. Sullivan of the New York World. The coloring is an unusually rich, deep rosy magenta overlaid garnet with silver shadings on edges of petals. A rich and beautiful combination of colors. Perfect, full cen'ters. Stems are strong and erect. Foliage leathery and repellent to insect injury. This greatly admired Dahlia is sure to please you. Stock of tubers limited. Tuber $\$ 7.00$. Plant $\$ 3.50$

TITAN (Dec.)-Imported creation of Dwarf habit and free flowering. Tuber $\$ 2.00$

UNCLE TOM (D.)-If you want the nearest to black of any Dahlia that grows you should have this one. This Dahlia was placed on the Dahlia Roll of Honor in the December issue of the Garden and Home Builder Magazine, 1926. It is deep garnet. almost black, as rich as the finest velvet in texture: and, as La Tulip Noir enriches the tulip gardens, so Uncle Tom gives a touch of color to the Dahlia gardens that is bost effective, different and artistic. The form is decorative. Keeps unusually well. It is a free bloomer of large blossoms held facing on good stiff stems. .... Tuber $\$ 2.00$

WILLIAM H. HOGAN (Dec.)-Winner first prize New York 1927. This is one of those Dahlias that must be seen to be appreciated. Color garnet-red with white tips running down the center of the petals. Perfect stems. Mr. Derrill W. Hart says "William H. Hogan, this heavy textured flower, carried out the prediction that we made for it last year, namely: that it was the best of the fancy varieties shown in $1927 . "$ It is without doubt the best fancy Dahlia on the market to date. The habits of the plant are perfect, the very large bloom are carried on very long stiff stems. It's a winner. .... Tuber $\$ 5.00$. Plant $\$ 2.50$

W. D. CARTWRIGHT-Color deep orange at center to orange-yellow at tips. Form massive, yet without a suggestion of coarseness, the finished flowers being partially reflexed, yet building up full in the center. Best of stems, early to flower and grand in every way. ......... Tuber $\$ 3.00$ 
WANDA MILLER (D.)-A new Dahlia. The same color as "Our Country," deep purple with white tips, never sports to solid color, large flowers held erect on very long stiff stems. Early and a free bloomer. ................ Tuber $\$ 2.00$

YELLOW PRINCESS (Dec.)-Joint introducers with the originator, Mr. Georg IV. Fraser. Certificated A. D. S. trial garden. Golden medal ribbon wnner New Iork show 1927. One of the largest yellow Dahlias that we have ever grown. Long stiff stems. ............... Tuber $\$ 5.00$

WHITE EMPRESS (D.) (Jost)-This new white Dahlia was a sensation at the New York and New Haven shows. At the American Dahlia Society show at Madison Square Garden it won the Darnell :up, 1928, as the best keeping variety in the show. At New Haven it received a Special Award of Merit. It is the ideal white Dahlia for the garden on account of its attractive appearance and sturdy growth. It is, we believe, the best all-round white Dahlia introduced to date.

Tuber $\$ 7.50$. Plant $\$ 3.50$

WINONA (Dec.)-Purplish-lavender, or shall we call it amethyst? It is a lively color that some people refer to as light purple but it is more properly, we think, a deep lavender. The center of the inner petals of this flower were inclined to a lighter shading. Planted in the front row of our garden, as the plant is rather dwart, IVinona certainly proved a valuable advertisement of large up-to-date Dahlias for us. Nothing could be more ornamental in a carden and we can recommend it as desirable from every point of view.

Tuber $\$ 2.50$

WHITE WINGS-A new clear white decorative with strong erect stems. Large blooms with good keeping qualities. Won a first prize in the decorative class at Palace Hotel show, San Francisco, 1927.

Tuber $\$ 2.00$

WALDHEIM SUNSHINE-This giant yet graceful Dahlia is one of the best. A true deep yellow that will show up yellow under artificial light. The reflex is darker, and there is a rich golden suffusion around the beautiful full, high center. The bush growth is good, stems are strong and erect. It is a sturdy grower and free bloomer. The centers were perfectly full when killed by frost.

Tuber $\$ 10.00$. Plant $\$ 5.00$

VALESKA (Dec.)-Deep lilac. There is no variation in color unless perhaps the lilac shade slightly deepens at the center. We would like to give a more vivid color picture if we could but are completely at a loss to do so, and can only say we know of no other Dahlia like it. The immense blooms have a deep rose-like formation with petals slightly curled and with a bewitchingly pointed center. The stem is first-class, and the growth of the plant luxuriant in the production of fine blooms. Taleska was included in our collection of unregistered seedlings at the Palace Hotel show. ......... Tuber $\$ 5.00$. Plant $\$ 2.50$

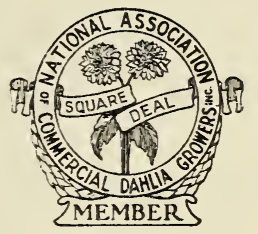

ANNOUNCEMENT

MARGARET E. BROOMALL-A monster pure white creation that is a giant among giants. Mr. Broomall says: "It is the best Dahlia that I have ever seen." We agree with him as we grew it about 14 inches last season; if there was ever a $100 \%$ Dahlia here it is. We have seen a few good ones and we have yet to find one fault in the wonderful Dahlia, a prolific bloomer, long stiff stems with flowers set in just the right position to always look you in the face, plants are of perfect formation, about 5-6 feet high and they are absolutely insect proof. The bloom will stay on the bush for weeks and remain in perfect condition and they will remain in perfect condition a week after being cut. Yes, this is the perfect Dahlia and we are sorry that we cannot release it this season, but our small stock will not permit. We might add that we have others that Mr. Derrill W. Hart wanted to put on the Honor Roll this year and in fact had their description prepared, but we thought we would wait until another season. We have some wonderful creations awaiting our customers other than the ones we are releasing this season. 


\title{
EVOLUTION OF THE DAHLIA
}

\author{
BY J. J. BROOMALL
}

(Chapter Thirteen)

\section{THE GREEN PLANT QUESTION}

In discussing "The Green Plant Question" I shall endeavor to give my reasons for being very much in favor of green plants, that is, growing Dahlias from cuttings, and I will also try to explain why green plants of Dahlias are sometimes disappointing and a failure.

It is more than thirty years since I raised my first Dahlia plants from cuttings. For many years while I was in the Mail Order business I sold so close on many of the better varieties of Dahlias that I did not have near enough roots to plant, so that I was practically forced to propagtate from cuttings in order to raise sufficient stock to meet the demand, with the result that quite often more than half my ground was filled with. green plants. The stock grown from such plants was almost without exception fully as satisfactory as stock grown from tubers. Some of the finest blooms I have ever obtained were produced by green plants, and in some varieties the blossoms were much more perfect and showed less tendency to produce flowers with open centers than the same kind grown from tubers.

On the other hand I have tried to raise Dahlias from green plants supplied by other growers that sometimes were far from satisfactory and in some cases a total failure. Now I proceed upcn the thecry that there is always a CAUSE for every effect whether the effect be good or bad, and I believe the most common cause for the failure of green plants is over-propagation by the use of too much artificial heat; the vitality of plants forced under excessive heat and unnatural environment is injured to such an extent that when grown they have not the strength necessary to produce perfect flowers, and, indeed, some are not strcng enough to survive long after being planted out or if they do manage to live prove to be only "stunts" that only get a few inches high all summer not having the strength to make a normal growth much less a blossom or even a bud. It is no wonder that people receiving such plants are disappointed and disgusted with green plants, and not understanding the cause we can hardly blame them for their poor opinion of green plants of Dahlias.

Right here I want to warn some of the Eastern Growers. and a few Californians as well that if they persist in this ruincus practice of excessive forcing they will not only be doing great harm to the Dahlia trade in general, but will injure themselves most of all, for disappointed custcmers caused by such tactics will surely prove a boomerang to their business.

When I receive a letter from a New Jersey customer in February telling me of the large number of cuttings he has started I KNOW that he must have used a great deal of heat; much more than is good for the vitality of the plants, and if persisted in the majority cf those plants will not pay for the trouble of planting them.

Now at the time that letter was received my clumps in the propagating bench had not even started to sprout although I am living in a much warmer climate than New Jersey. I am well aware of the fact that some of my fellow growers think I am slow and dd-fashioned in $m y$ propagating but $I$ had rather be two or three months behind the other fellow with my green plants than to have a lot of irate customers looking for me at the Fall Flower Show.

Here is how I start my green plants: I bed my clumps in the propagation bench using a mixture of sandy loam and ground peat, the first week in January, using sufficient dirt to cover the tubers, but leaving the crown even with the surface with little or no earth over it (the crown). I never use any heat under the bench containing the clumps, and very little under the cutting bench. In fact, I make no effort to keep the temperature above 50 at night or in cloudy weather and do not worry if it falls to 40 on a frosty night although I do not advise such a low temperature as 40 , but at all times 1 try to have air circulating, in fact try to keep conditions as near natural as possible without getting too near the freezing point.

Naturally, under these conditions. the Dahlias are slow in starting so that I seldom get many cuttings before the latter part of March and do my heariest propagating in April and May, the most of my plants not being ready for planting in the field (after being 
potted and hardened off in the lath house) until June and the later ones in July. After they get well started they grow rapidly and by Fall are blooming profusely and the most of them produce a fair crop of healthy tubers.

It is generally the practice to root the cuttings in pure sand, and they should be potted in 2 1-2-inch pots as soon as rooted. If they only have one rootlet not more than one-eighth inch long it is safe to pot them, and is much better than leaving them in the sand too long as the sand contains very little plant food and cuttings left in it too long will develop a lot of stringy roots that are half-starved for nourishment and not good ior the vigor of the plants.

I believe a mixture of leaf-mold with the sand is better for Dahlia cuttings as the leaf-mold contains plenty of plant food so that the growth will not be weakened by remaining longer in the bench. There may be more danger of damping off if leaf-mold is used as it is apt to contain some fungus unless it has been baked, but if plenty of air is in circulation there is not much danger of damping off as the most frequent cause of damping of fungus in the cutting bench is STAGNANT AIR AND TOO MUCH ARTIFICIAL HEAT.

The first Dahlia cuttings I ever grew were rooted about 1897 out of doors in virgin soil that contained a liberal mixture of leaf-mold derived principally from maple trees; those cuttings grew in a remarkably short time and bloomed to perfection. But that was in Snohomish County, Washington, where conditions happened to be "just right" and would seldom be practicable here or in many other localities.

It is, however, not strictly necessary to have a hot-house in which to grow Dahlia plants successfully. For many years I grew my green plants in hot-beds with satisfactory results except, for instance, when a toad seemed to think the sand a proper place in which to bury himself and upheaved quite a number of cuttings in so doing-but whatever you do, DON'T KILL THE TOADS: they are our friends.

There is one great advantage in using hot-beds: in warm sunshiny weather the tops can be removed entirely and the plants will be outdoors under natural conditions and remember-the nearer we keep to natural conditions the more satisfactory the plants will be, such plants will be almost certain to give satisiaction.

I do not propose to take up the matter of stunts now only to say that I do not want it understood that excessive propagation is the ONLY cause of stunts in Dahlias, it is ONLY ONE OF THE CAUSES; stunted growth or lack of growth may be due to the sting of some injurious insect or various other causes as yet unfathomed. The efforts of some writers to place all the blame for stunts on green plants is absurd.

The reason that green plants do not always produce tubers is that sometimes the cutting has been rooted between joints. Such plants may grow and bloom but unless they are planted deep enough so that a joint is three inches below the surface they may not throw out tubers. Heel cuttings are far the best as they root more easily and are sure to make tubers. Where other cuttings are used they must be planted deep enough to insure the proper covering of a joint. I generally set my plants in a small trench or cavity so that by the time they are half-grown and the soil is about level from being cultivated the plants will be six inches deep, for it is better to err on the side of deep planting than not to plant deep enough.

I wish to say to our friends who are in a big hurry to increase their stock of a new variety that there is a way it can be done successfully out of doors under natural conditions without injuring the vitality of the Dahlia. Stock grown by the method I shall describe will not be suitable for filling orders but will be good for home planting, producing roots that will be good for commercial use the following season.

To the curious I will say that it will be useless to write for an explanation of this method; it will be described fully in my book on the "Evolution of the Dahlia," which I hope to be able to publish within a year in which I will endeavor to the best of my ability to give others the benefit of my experience of a third of a century of Dahlia Culture.

Yours for Better Dahlias, 


\section{ORDER SHEET \\ Issued by \\ Success Dahlia Gardens \\ 1 I 1 FERRY STREET, LAWRENCE, MASS.}

Date

Amount Enclosed

Your Name

(Write it plainly. Ladies will please use the prefix Miss or Mrs.)

City.

Street

State

County

Shall we substitute for any that are sold out?

About what date do you want them shipped?

\begin{tabular}{l|l|l|l}
\hline \hline HOW & HOW & & PRICE \\
MANY & MANY & NAME OF DAHLIA & PLLBS \\
PLANTS &
\end{tabular}




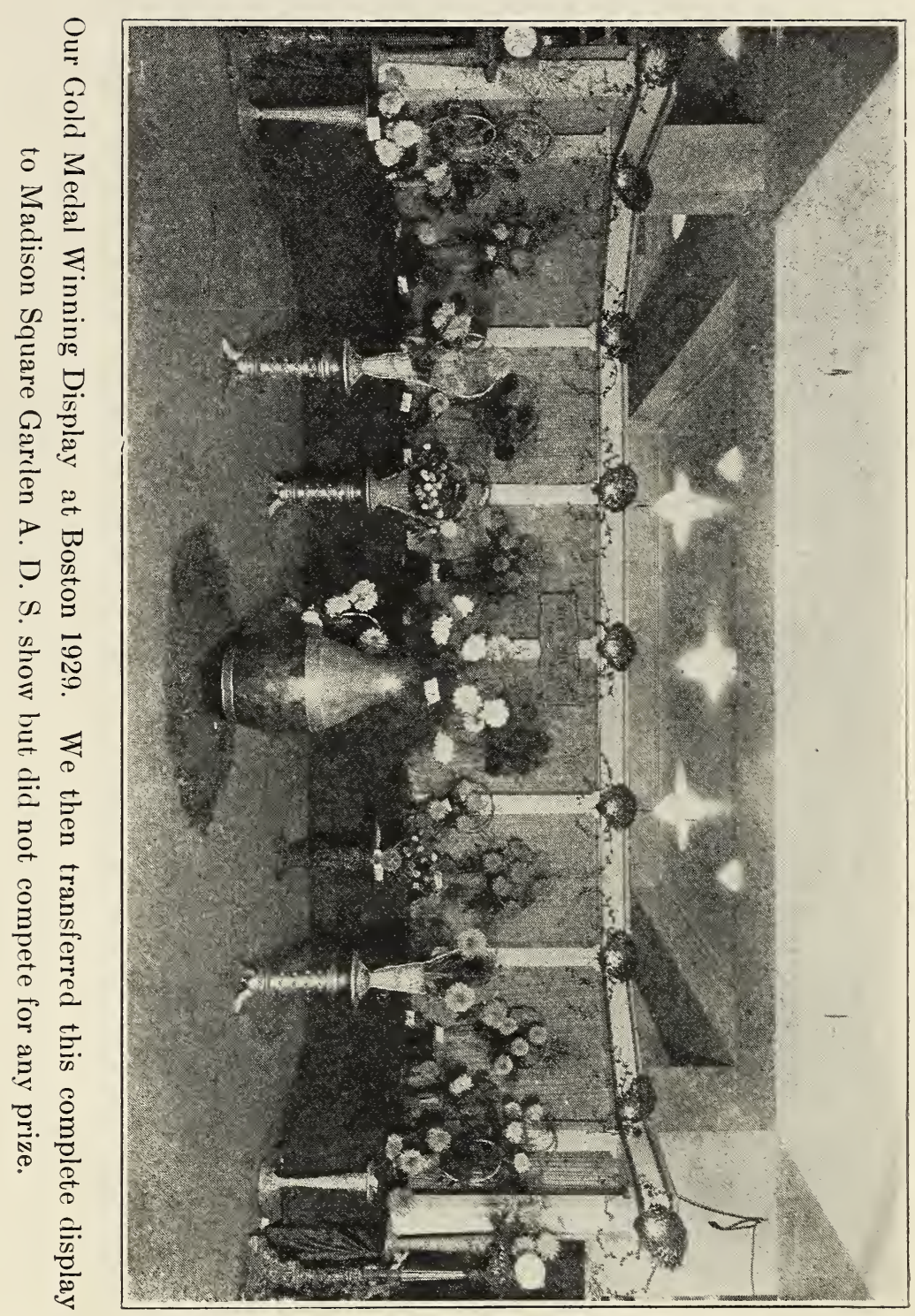




\section{JOIN THE AMERICAN DAHLIA SOCIETY, INC.}

Wm. J. Rathgeber, Sec'y.,

198 Norton Street,

New Haven, Conn.

I extend to you a most cordial invitation to join this live organization that has done so much in making the Dahlia the most talked flower in the flower world today. There are four fine Bulletins issued each year devoted almost exclusively to the Dahlia and they are brimfull of interesting articles written by the amateur and commercial grower. They tell you all about the new Dahlias, the trial garden report. how to grow Dahlias, reports of the Dahlia shows, etc.

I am sure that the secretary will be pleased to send you a sample copy of the Bulletin on request. Don't wait, send in your $\$ 2.00$ today which pays for your dues and subscription for the Bulletin for one year.

CHARLES G. REED,

Vice-President.

\section{AMERICAN DAHLIA SOCIETY OFFICIAL TRIAL GARDEN Storrs, Conn.}

Hundreds of our customers are growing seedlings and of course many think they have better seedlings or as good as some of the high priced Dahlias and perhaps they have. BUT to be sure they should send them to this garden and this is one way to find out. It will cost you just a $\$ 2.00$ bill for each variety that you send, but you may send three tubers or plants of each variety with no extra charge; this insures the sender that at least one plant should be at its best at judging time. The clumps made from your varieties will be returned to you in the fall after digging if you wish, but you must pay the return express charges which amounts to very little. Why not send at least one variety this year and more if possible and what a fine investment if you produce a winner. Remember Jane Cowl, Elite Glory, Jersey Beauty, Alice Whittier and hundreds of other great Dahlias received their start at the trial garden at Storrs. Just drop a line to Prof. Roland H. Patch, Storrs, Conn., and he will gladly send you full instructions when to ship and etc. You know we are going to install an up-to-date sprinkling system there next spring and expect to have a glorious garden to greet the visitors next season. Help us make it so. Please.

CHARLES G. REED, Chairman

Trial Garden Committee.

\section{NATIONAL ASSOCIATION OF COMMERCIAL DAHLIA GROWERS, INC.}

Every reputable commercial dealer or grower should join this live association. Purchasers of Dahlia stock are assured of a "Square Deal" if they purchase stock from a member. For full particulars drop a line to Mr. Thomas Leavitt, Sec'y., Assinippi, Mass. 


\section{LAWRENCE, MASSACHUSETTS}

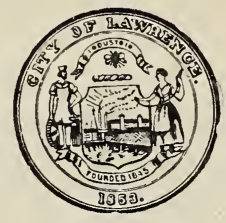

Where the world's largest worsted mill and the world's largest print works are located, will soon have, also, the world's largest

$$
\begin{gathered}
\text { RADIO TUBE PLANT, } \\
\text { DECORATIVE LIGHTING CONCERN, } \\
\text { HARD RUBBER COMB FACTORY }
\end{gathered}
$$

\section{LAWRENCE}

Added 25 new industries in 1929 and will add still more in 1930. These concerns are attracted to Lawrence

BECAUSE
OF ITS $\left\{\begin{array}{l}\text { Low Tax Rate } \\ \text { Large Supply of Skilled Labor } \\ \text { Cheap Power } \\ \text { Excellent Transportation Facilities }\end{array}\right.$

LET US TELL YOU WHY SO MANY CONCERNS ARE MOVING TO LAWRENCE. Write to LAWRENCE INDUSTRIAL BUREAU

1-2 ESSEX BANK BUILDING, LAWRENCE, MASSACHUSETTS, U. S. A.

\section{WE WILL REPLY TO}

Name

Firm

Street

City

State

CLIP THIS OCT and mail it. It will bring you some valuable information and it will not obligate you in any way.

This space donated to the Lawrence Industrial Bureau by the courtesy of Charles G. Reed. 